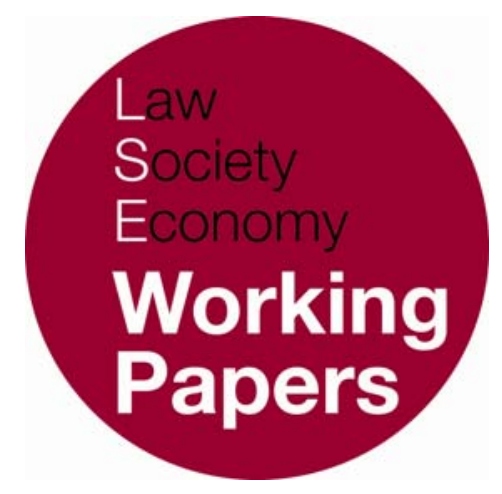

\title{
Who is the New European Refugee?
}

\author{
Nadine El-Enany
}

LSE Law, Society and Economy Working Papers 19/2007

London School of Economics and Political Science

Law Department

This paper can be downloaded without charge from LSE Law, Society and Economy Working Papers at: www.lse.ac.uk/collections/law/wps/wps.htm and the Social Science Research Network electronic library at: http://ssrn.comabstract=1033334.

(C) Nadine El-Enany. Users may download and/or print one copy to facilitate their private study or for non-commercial research. Users may not engage in further distribution of this material or use it for any profit-making activities or any other form of commercial gain. 


\title{
Who is the New European Refugee?
}

\author{
Nadine El-Enany ${ }^{*}$
}

\begin{abstract}
This paper highlights the unforeseen or unintended effects of the European Union's refugee law on the world's most vulnerable refugees, those forgotten by the law. The paper focuses on those refugees automatically denied protection in Europe by being impliedly defined out of the EU's refugee definition. Not only must refugees seeking protection in Europe meet the legal definition, but they are also assumed to have the means to reach Europe. Due to the limitations on legal access routes, often only those who can afford to pay a smuggler have the chance to reach Europe. The great majority of the world's refugees remain outside Europe. Therefore, an exploration of the external policies of the EU institutions which are designed to counter the limiting affects of its restrictive migration policy is required. The paper examines the move towards the establishment of Regional Protection Programmes, Protected Entry Procedures and Resettlement Schemes as providing possible hope for enduring protection for those refugees trapped outside Europe.
\end{abstract}

\section{INTRODUCTION}

It may be said that EU refugee law generally broadens protection for asylum seekers and refugees in Europe, though when seen in the light of wider EU migration policy, it is clear that access to EU asylum procedures has been severely impaired in recent years. The result has been a change in the identity of the European refugee, whose routes of accessing the EU, having been strictly curtailed, must now possess certain characteristics such as an element of power and economic mobility in order to penetrate the European border. These individuals are by no means the most vulnerable refugees. The EU's recent moves to counter the implications of its restrictive migration policy on access to Member States' asylum procedures through the use of such measures as Regional Protection Programmes, an EU-wide Resettlement Scheme and Protected Entry Procedures, if managed effectively, may provide the beginnings of a positive step towards

\footnotetext{
* PhD Researcher at the European University Institute, Florence. The author would like to thank Damian Chalmers and Bruno de Witte for comments on earlier drafts of this paper. Any omissions are the author's alone.
} 
providing pragmatic and equitable protection to vulnerable refugees. The evolution of the identity of the European refugee is first explored with reference to the relevant international law and then within the framework of the EU Qualifications Directive. There follows a discussion on the nature of the European refugee in the context of the EU's restrictive migration policy. Finally, the proposals of the European Commission, designed to alleviate the negative implications of the limited access to the EU, are explored.

\section{THE 1951 REFUGEE CONVENTION}

\section{WHO IS A 'REFUGEE'?}

The primary source of international protection for those seeking refuge is the 1951 Refugee Convention. Before examining the Convention definition of a 'refugee', it may be useful to explore the intuitive and conceptual dimension of the term. Goodwin-Gill writes that "implicit in the word "refugee" lies an assumption that the person concerned is worthy of being, and ought to be, assisted, and, if necessary, protected from the causes and consequences of flight'. ${ }^{1}$ The interesting question is what is to account for this 'implicit assumption'? The use of the term 'refugee' suggests some preconceived idea of a person who is envisaged as deserving of protection; we know what a refugee looks like before she has arrived. The definition of a refugee is formulated on the basis of this image and to start with was done so retrospectively. During the Second World War a great many individuals fled across borders in order to escape persecution. When it came to the task of creating a general definition of a refugee during the negotiations on the Refugee Convention, this was moulded to fit those already on the States' territories. Categories were formulated of 'existing refugees, while the general criterion of persecution or fear of persecution, neither narrow nor excessively restricted... was considered broad enough for post-Second World War and future refugees'. ${ }^{2}$ The drafters therefore had a clear idea of who they wanted to fall within the scope of the refugee definition and opted for a more general wording so that changes could be accommodated in the future.

States have always preferred to make clear to whom they are willing to provide protection and from what. Traditionally, the essential quality of a refugee was seen to be her presence outside her own country as a result of political persecution. ${ }^{3}$ However, by the end of the Second World War it had become apparent that persecution could take place on a number of grounds other than one's political opinion and the definition of a refugee was widened to include grounds of persecution such as race and religion. This is demonstrated in the

${ }^{1}$ G. Goodwin-Gill, The Refugee in International Law (Oxford: Oxford University Press, 1996) 3.

2 ibid 19.

${ }^{3}$ J. H. Simpson, Refugees-A Preliminary Report of a Survey (1938), 1 cited in ibid 5. 
definition of a refugee eventually settled upon in the 1951 Refugee Convention, which states that a refugee is a person who:

[...] owing to a well-founded fear of being persecuted for reasons of race, religion, nationality, membership of a particular social group or political opinion, is outside the country of his nationality and is unable, or owing to such fear, is unwilling to avail himself of the protection of that country; or who, not having a nationality and being outside the country of his former habitual residence as a result of such events, is unable or, owing to such fear is unwilling to return to it $[\ldots]^{4}$

Recognition as a refugee therefore requires an individual to have crossed an international border and to have suffered some sort of discriminatory human rights breach. Proof of persecution alone is not sufficient to establish refugee status; the threat to the individual's life or liberty must have a discriminatory impact on the basis of her 'race, religion, nationality, membership of a social group or political opinion'. ${ }^{5}$ Though the term 'persecution' is not itself defined, certain types of harm have traditionally been seen as falling within its scope of meaning whilst others not. For example, individuals fleeing poverty are not generally considered deserving of asylum. 'The solution to their problem, perhaps, lies more within the province of international aid and development, rather than in the institution of asylum'. ${ }^{6}$ Furthermore, traditionally those individuals who flee the criminal justice system after committing a crime (of a non-political nature) are excluded from refugee protection. ${ }^{7}$ However, apart from these well-known exclusions from the scope of refugee law, difficulties do arise when trying to draw its limits. The EU Qualifications Directive has attempted to address this point by setting out examples of harms that are to be considered as amounting to persecution. An important point to bear in mind concerning any definition of a refugee is that it will always seem arbitrary, however wide its scope of protection. At best it can be argued to reflect the host society's view of what harms are considered so untenable that both non-nationals and nationals of a host State are entitled to be protected from at all costs. As host States develop over time, this list tends to lengthen and thus the refugee definition, and its scope of protection, broadens.

\section{FROM 'REFUGEE' TO 'ASYLUM SEEKER': THE PRINCIPLE OF NON- REFOULEMENT}

The principle of non-refoulement is consistently hailed by commentators as being the most critical of obligations set out in the Refugee Convention to be adhered to by

${ }_{4}$ Article 1(A)(2), Refugee Convention.

${ }^{5}$ D. E. Anker, 'Refugee Law, Gender, and the Human Rights Paradigm' (2002) 15 HHRJ 134.

${ }^{6}$ G. S. Goodwin-Gill, $n 1$ above, viii.

7 ibid 3. 
States. Article 33(1)(A) of the Refugee Convention, which prohibits refoulement reads:

No Contracting State shall expel or return ("refouler") a refugee in any manner whatsoever to the frontiers of territories where his life or freedom would be threatened on account of his race, religion, nationality, membership of a particular social group or political opinion.

Though the broadening of refugee law since the agreement of the Refugee Convention is to be welcomed, there has evidently been a parallel tendency towards the implementation of increasingly restrictive practices designed to reduce the number of individuals arriving on European shores. As limitations on access to the EU increase, the relevance of any refugee definition decreases. A broad refugee definition without asylum seekers to meet its criteria serves little purpose. States have not only responded positively to the increasing humanitarian pressure to widen their protection regimes, but have also responded to the high number of claims for protection by placing barriers in the way of those seeking protection, for example through the use of visa regulations, carrier sanctions and concepts such as the 'safe country'.

Demonstrative of the increase in restrictions to access to protection is the terminological and ideational shift over the last decades from 'refugee' to 'asylum seeker'. The implicit assumption contained in the use of the word 'refugee' is critical to understanding this terminological shift. Unlike the term 'refugee', the idea of an 'asylum seeker' depicts a figure whose characteristics are unknown. The asylum seeker is merely an individual claiming to be a refugee and thus there is the possibility that the claim is unfounded or that the person deserves protection for reasons which fall outside the scope of refugee law. Until the claim is heard it is considered unsubstantiated and thus does not give rise to rights under refugee law.

A number of provisions in the Schengen Agreement ${ }^{8}$ concerned 'the hitherto unknown asylum seeker'. 9 Although the phrasing in the Schengen Agreement, which described an asylum seeker as 'an alien at the border or within the territory of a Contracting Party' making an asylum application 'with a view to obtaining recognition as a refugee in accordance with the Geneva Convention.... and as such obtaining the right of residence', ${ }^{10}$ betrays little of the way in which the signatory States perceived asylum seekers, the Qualifications Directive better expresses the inherent suspicion or perhaps even presumption of falsity with regard to the claim of an asylum seeker. In Article 4(3)(d) of the Directive, Member States, in assessing the 'facts and circumstances' of an applicant's claim, are to consider 'whether the applicant's activities since leaving the country of origin were engaged

8 The 1985 Schengen Agreement was signed in 1985 and is designed to facilitate the abolition of systematic border controls between the State Parties. It was followed by the Schengen Convention, which came into force in 1995.

${ }^{9}$ C. Teitgen-Colly 'The European Union and Asylum: An Illusion of Protection' (2006) 431 CMLR 506.

10 The Schengen Convention, Article 1. 
in for the sole purpose of creating the necessary conditions for applying for international protection'. Thus, in contrast to the situation concerning refugees, in the case of an 'asylum seeker', the implicit assumption that the individual is worthy of protection is lacking. Rather, in hand we have a potential refugee; an individual whose claim for protection must be assessed for credibility prior to the granting of rights under refugee law.

The phenomenon of an asylum seeker is a difficult one. Commentators have tended to use the term refugee and asylum seeker synonymously in order to emphasise the applicability of the principle of non-refoulement to all individuals claiming protection. The rationale prevalent among scholars in the field is that recognition of a refugee's status does not 'make him a refugee', but merely 'declares him to be one'. ${ }^{11}$ Thus, Article 33 necessarily implies that the status of an applicant is to be determined by the State in which she lodges her claim before any deportation can legitimately take place. Failing this, a State could not be certain that it is adhering to the principle of non-refoulement. In theory, therefore, all asylum seekers may be said to benefit from a 'presumptive refugee status' whereby 'an applicant has the same [Article 33] rights as a refugee unless and until his or her non-refugee status has been established'. ${ }^{12}$ On this interpretation of the law, the principle of non-refoulement applies to all individuals regardless of the country from which they originate or any circumstances surrounding the credibility of their claim to protection. The response from States has been to limit the number of individuals fulfilling the status of an asylum seeker in order to cope with the demands of the principle of non-refoulement on this absolute interpretation. One way in which States have responded is with the introduction of the 'safe country' concept in the administration of their asylum regimes; a procedural measure designed to reduce the amount of asylum claims to be determined. If an individual lodging an asylum application in a destination State is found to have originated from, or passed through, a so-called 'safe country', her claim may be left undetermined and she becomes liable to return to that 'safe country'. A country is presumed 'safe' on consideration of a number of factors, including its human rights record and its political situation. The precarious nature of the criteria used means that presumptions of safety are open to allegations of being unjustified.

The practical pressures upon States to respect the principle of non-refoulement, in spite of the increased number of claims in the early 1990s which led to administrative burdens, public hostility towards asylum seekers and the use of the refugee route as a backdoor to economic migration, along with the lack of effective enforcement of the Refugee Convention, have rendered adherence to the law under such liberal interpretations of the Convention as discussed above both impossible and avoidable in practice.

11 Office of the UNHCR, Handbook on Procedures and Criteria for Determining Refugee Status (1979; re-edited 1992) at [28].

12 J. Vedsted-Hansen, 'Non-admission policies and the right to protection: refugees' choice versus states' exclusion?', in F. Nicholson and P. Twomey (eds.), Refugee Rights and Realities: Evolving International Concepts and Regimes (Cambridge: Cambridge University Press, 1999) 275 and 276. 
The main problem concerning the principle of non-refoulement is its absolute nature. It is not only impossible in practice, but also unwise to attempt to implement generally an absolute principle of any kind, including that of nonrefoulement under the traditional interpretation of asylum advocates that it gives rise to a presumptive refugee status applicable to every person claiming protection no matter from where she originates. In order to illustrate this point it is possible to explore the application of a procedural measure such as the 'safe country of origin'. Claims originating from designated 'safe countries of origin' are treated as a priori inadmissible and applicants are precluded from protection, unless they can rebut the presumption against their claim. Concerns as to the use of the concept of a 'safe country of origin' have been raised by a number of commentators. ${ }^{13}$ Goodwin-Gill has asked, 'How can we be sufficiently sure that even the most reputable of regimes has not, just this once, produced a refugee?'. ${ }^{14}$ Van Selm has likewise noted that any State's safeguards against persecution 'might fail a tiny minority' who would then be precluded from seeking protection elsewhere. ${ }^{15}$ Although such arguments are valid theoretically, their implication is the adoption of a 'one size fits all' approach to the examination of claims, which, for example, would see a claimant originating from the Democratic Republic of Congo arriving in France, treated in the same way as an individual coming from Germany. This cannot be a prudent or a just allocation of resources considering a common sense evaluation of the situation in these States of origin.

The principle of non-refoulement was devised at a time when States knew the nature of the individuals arriving at their borders. It was designed to work in conjunction with the definition of a refugee. By defining a refugee, States claimed to know their characteristics and to accept the obligation of providing them with protection. However, with the emergence of the potential refugee or the asylum seeker and the subsequent burden on asylum administrations, States were compelled to devise a new notion of non-refoulement. It is possible to conceive of the 'safe country' concept as precisely this. By using this measure, States are purporting to know who counts as a refugee before they have arrived and, just as before, only grant a right to non-refoulement to those pre-identified as having a claim to protection. This is the same method and reasoning that was used to distinguish a refugee from a non-refugee at the time of the negotiations on the Refugee Convention. States merely responded to circumstances prevailing at the time of its agreement, just as States have done over the previous decades. However, the

\footnotetext{
${ }^{13}$ See for example, C. Costello, 'The Asylum Procedures Directive and the Proliferation of Safe Country Practices: Deterrence, Deflection and the Dismantling of International Protection?' (2005) 7 EJML 50; J. Van Selm, 'Access to Procedures: "Safe Third Countries", "Safe Countries of Origin" and "Time Limits", (Paper commissioned by UNHCR and the Carnegie Endowment for International Peace, 2001) 37; J. Allain, 'The jus cogens nature of non-refoulement' (2002) 4 IJRL 13, 549; R. Byrne and A. Shacknove, 'The Safe Country Notion in European Asylum Law' (1996) 9 HHRJ 192.

${ }^{14}$ G. Goodwin-Gill, 'Safe Country? Says Who?' (1992) 4 IJRL 242.

15 J. Van Selm, 'Access to Procedures: "Safe Third Countries", "Safe Countries of Origin" and "Time Limits" (Paper commissioned by UNHCR and the Carnegie Endowment for International Peace, 2001) $35-6$.
} 
effect has been an increasing number of restrictive measures preventing asylum seekers, whether genuine or not, from seeking protection in European countries.

\section{WHO IS A EUROPEAN REFUGEE?}

\section{The Qualifications Directive}

Being the most recently formulated refugee law in Europe, for its participants, the Qualifications Directive marks the stage at which refugee law has developed since the 1951 Refugee Convention. Though the Directive leaves scope for national practices which do not fall below the minimum standards contained within, it is clear that it represents the most recent European statement of refugee law and will thus act as the springboard for developments. The Directive sets out the rules and principles to be applied by Member States in their identification of refugees and those deserving of subsidiary protection status. The Directive covers both refugee status as laid down in the Refugee Convention as well as subsidiary protection status, applicable to those who do not qualify as refugees, but are at risk of suffering serious harm. ${ }^{16}$ In general the Directive has a broad scope of protection which is to be welcomed. In some areas it goes further than the Refugee Convention, for example with regard to its recognition of non-State actors as being capable of persecution. ${ }^{17}$

\section{Definition of a 'refugee'}

The Qualifications Directive defines a refugee as:

$[\ldots]$ a third country national who, owing to a well-founded fear of being persecuted for reasons of race, religion, nationality, political opinion or membership of a particular social group, is outside the country of nationality and is unable or, owing to such fear, is unwilling to avail himself or herself of the protection of that country, or a stateless person, who, being outside the country of former habitual residence for the same reasons as mentioned above, is unable or, owing to such fear, unwilling to return to it $[\ldots]^{18}$

Although the definition of a refugee found in the Qualifications Directive is taken almost word for word from the Refugee Convention, its true meaning and

\footnotetext{
${ }^{16}$ Qualifications Directive, Article 2(e).

17 Article 6 of the Qualifications Directive, which covers the 'Actors of persecution or serious harm', is a welcome development in European refugee law. Aside from the State (Article 6(a)), the Directive recognises that 'parties or organisations controlling the State or a substantial part of the territory of the State' are also capable of persecution (Article 6(b)) as well as acknowledging the capability of 'non-state actors' to persecute or inflict serious harm (Article 6(c)).

${ }^{18}$ Qualifications Directive, Article 2(c).
} 
substance cannot be found solely through reference to the Convention. Rather the significance of the refugee definition is located in the meanings attributed by the EU Member States to 'persecution', and in the grounds of persecution they have drawn up in the Qualifications Directive. According to the Directive, the definition may in fact, in a number of respects, be seen as broader than that found in the Refugee Convention in its consolidation of the developments in refugee law since the time of the agreement of the Convention.

\section{'Acts of persecution' and 'Reasons for persecution'}

It is clear from Article 9 on 'acts of persecution' and Article 10 on 'reasons for persecution' that an element of discrimination must be present in any case made for asylum. The substance of these provisions reflects the growing intolerance of certain forms of discrimination in Europe. ${ }^{19}$ These provisions fall under Chapter III of the Directive on 'qualification for being a refugee'. The unacceptability of certain harms and particular grounds of discrimination in Europe is demonstrated in their applicability not only to Europeans, but also to those seeking protection in Europe.

In respect of the types of harm from which individuals may seek protection, although 'persecution' is not defined as such, the Directive states in Article 9(1)(a) and (b) that 'Acts of persecution within the meaning of article $1 \mathrm{~A}$ of the [Refugee Convention] must:

(a) be sufficiently serious by their nature or repetition as to constitute a severe violation of basic human rights, in particular the rights from which derogation cannot be made under Article 15(2) of the [European Convention on Human Rights]; or (b) be an accumulation of various measures, including violation of human rights which is sufficiently severe as to affect an individual in a seminal manner as mentioned in (a).

'Severe violations' of 'basic human rights' are likely to be restricted to Article 2 (right to life), Article 3 (freedom from torture and inhuman and degrading treatment or punishment), Article 4(1) (freedom from slavery) and Article 7 (prohibiting the retrospective application of criminal law) of the European Convention of Human Rights. The Directive provides a non-exhaustive list of persecutory acts, including 'acts of sexual violence' 20 and 'acts of a gender-specific

\footnotetext{
19 See Council Directive 2000/43/EC of 29 June 2000 implementing the principle of equal treatment between persons irrespective of persons of racial or ethnic origin [2000] OJ L 180/22; Council Directive 2000/78/EC of 27 November 2000 establishing a general framework for equal treatment in employment and occupation [2000] OJ L 303/16; Directive 2006/54/EC of the European Parliament and of the Council of 5 July 2006 on the implementation of the principle of equal opportunities and equal treatment of men and women in matters of employment and occupation OJ L 204/23; Council Directive 2004/113/EC of 13 December 2004 implementing the principle of equal treatment between men and women in the access to and supply of goods and services [2004] OJ L 373/37.

20 Article 9(2)(a).
} 
nature', ${ }^{21}$ neither of which are found in the Refugee Convention though the law has developed gradually in recognition of the need to protect individuals from return to such treatment. ${ }^{22}$

Article 9(3) of the Directive recalls the requirement in the Refugee Convention for a link between the reasons for persecution and acts of persecution. Under Article 10 Member States are obliged to take a number of factors into account when assessing the reasons for persecution. These include 'the concept of race...colour, descent, or membership of a particular ethnic group', ${ }^{23}$ 'religion', ${ }^{24}$ 'political opinion', ${ }^{25}$ 'nationality'26 and membership of 'a particular social group'. ${ }^{27}$ In contrast to the Refugee Convention, the Directive usefully provides a definition of a social group by stating some of the possible characteristics of such a group:

- members of that group share an innate characteristic, or a common background that cannot be changed, or share a characteristic or belief that is so fundamental to identity or conscience that a person should not be forced to renounce it, and

- that group has a distinct identity in the relevant country, because it is perceived as being different from the surrounding society.

Importantly the Directive recognises that 'a particular social group might include a group based on a common characteristic of sexual orientation'. However, a limitation is placed on the application of this provision: "Sexual orientation cannot be understood to include acts considered to be criminal in accordance with national law of the Member States." 28 With regards to gender, the Directive provides that: "Gender related aspects might be considered, without by themselves alone creating a presumption for the application of this Article." 29

Teitgen-Colly points out that the limitation attached to the basing of an asylum claim on grounds of one's sexual orientation represents the 'limits of the

${ }^{21}$ Article 9(2)(f).

22 See for example cases on female genital mutilation such as the decisions of the Immigration and Refugee Board Convention Refugee Determination Division (Toronto, Canada) of 1994, in 6 IJRL 662 (1994); the 'Tribunal Administratif de Lyon' (France), 12 June 1996: Revue Trimestrielle des Droits de l'Homme 695 (1996), cited in A. Fabbricotti, 'The Concept of Inhuman and Degrading Treatment in Asylum Cases' (1998) 10 IJRL 657; See also Human Rights Committee Conclusions making it clear that deportations of female asylum seekers with 'a well-founded fear of genital mutilation' are in violation of Article 7 ICCPR, which protects individuals from subjection 'to torture or to cruel, inhuman or degrading treatment or punishment'. Concluding Observations on the Netherlands (2001) UN doc. CCPR/CO/72/NET, at [11]; Concluding Observations on Lesotho (1999) UN doc. CCPR/C/79/Add. 106, at [12]; Concluding Observations on Sudan, (1997) UN doc. CCPR/C/79/Add. 116, at [12]; Concluding Observations on Egypt, (2002) UN doc. CCPR/CO/76, at [11]; Concluding Observations on Yemen (2002) UN doc. CCPR/CO/75/YEM, at [6]; Concluding Observations on Sweden, (2002) UN doc. CCPR/CO/74/SWE, at [8].

23 Article 10(1)(a).

${ }^{24}$ Article 10(1)(b).

25 Article 10(1)(e).

26 Article 10(1)(c).

27 Article 10(1)(d).

28 ibid.

29 ibid. 
harmonization exercise'. ${ }^{30}$ Importantly however, the inclusion of this proviso seems also to reflect the true limits of refugee law, i.e. that it may not develop further than the host society itself has developed in terms of the acceptability or otherwise of limits on rights and freedoms. It is clear from the above provisions on sexual orientation and gender as reasons for persecution that the approach taken in the Qualifications Directive towards defining the scope of refugee law is one based on the development of the Member States' societies. So for example, although sexual orientation can be considered a ground for determining persecution, this is limited to the extent that freedom of sexual orientation is protected in Member States. This supports the view that refugee law may only continue to develop in practice so long as it reflects the values of the host society. This can also be seen in Article 2(h) on the definition of 'family members', which includes:

- the spouse of the beneficiary of refugee or subsidiary protection status or his or her unmarried partner in a stable relationship, where the legislation or practice of the Member State concerned treats unmarried couples in a way comparable to married couples under its law relating to aliens [emphasis added].

This constant checking by host States of the breadth of their refugee law to ensure that it does not go beyond the scope of their own national standards of protection demonstrates the clear limitations attached to the potential widening of the scope of refugee law.

In many respects therefore the Qualifications Directive goes further in its scope of protection that the Refugee Convention. This is unsurprising considering the development over time of host societies and the increasing unacceptability of certain human rights violations. However, this broadening of refugee law is not the case throughout the Directive, reflecting the often parallel restrictions imposed on certain areas of an asylum regime in spite of widening its scope of protection in other areas. For example, although Article 4(4) on the 'Assessment of facts and circumstances' states that evidence of previous persecution or serious harm or threats of such treatment consists of 'a serious indication of the applicant's wellfounded fear of persecution or real risk of suffering serious harm', this is tempered with 'unless there are good reasons to consider that such persecution or serious harm will not be repeated'. Although this provision has been criticised for not taking into account the Refugee Convention's inclusion of a clause which makes clear that refugee status does not cease where the person invokes 'compelling reasons arising out of previous persecution', 31 arguably the limitation in the Qualifications Directive is justified in its attempt to find a means of dealing with applications in a manner which allows for fair and efficient distribution of scarce

\footnotetext{
${ }^{30} \mathrm{n} 9$ above, 1532

${ }^{31}$ Article 1(C)(5) and (6), Refugee Convention. See n 9 above, 1522.
} 
resources. In any case it has always been required that the applicant's fear of persecution be 'well-founded'.

It has been asserted that an 'atmosphere of circumspection' surrounds the approach of the Qualifications Directive towards asylum applications. ${ }^{32}$ It is submitted however that this is neither surprising nor wholly undesirable considering the way in which refugee law has developed over the years. Rather, such 'suspicion' with regard to asylum applications is to be expected in light of the shift from the idea of a known refugee to an unknown asylum seeker. The presumption of credibility might have been justified when States knew the makeup of the individuals claiming protection at their borders, but this has disappeared as the nature of European asylum law has changed drastically with the permanent flow of applications caused by continuous conflict across the World as well as the limitations placed on legal immigration routes. The important point to bear in mind is that for the refugee reaching Europe, the protection she is met with, at least in terms of the Qualifications Directive, is generally broad in scope.

\section{WHO IS THE REAL EUROPEANREFUGEE?}

This section explores those elements of refugee law and particularly of the refugee definition which cannot be found in stated refugee law, neither at the international, European, nor State level. Aside from stated refugee law, there are important elements which become evident when we consider European migration policy in general. One of the implications of this is that the European refugee has a number of implicitly required characteristics which are not obvious from refugee legislation.

At present, as is clear from the above, access to EU asylum procedures is far from equitable. There are individuals in need of protection, but who cannot penetrate the EU and the Member States' restrictive control measures on migration. It is therefore clear that the Member States have achieved their goal of trying to keep out of the EU as many asylum seekers as possible. From looking at the figures of asylum claims lodged over the last few decades, there has been an obvious decrease in the number of applications for asylum lodged in the EU and a parallel admission from the Commission that this does not necessarily mean that the number of those individuals in need of protection has decreased. ${ }^{33}$ While the EU moves to consider how better to facilitate access to Member States' asylum procedures, it is interesting to consider those persons who are fortunate enough to have gained international protection, either in the form of refugee or subsidiary protection status, in the EU. These are the new European refugees. They are the outcome of the rapid and extensive changes made to European asylum law and policy over recent decades. Who are they? What particular characteristics do they

32 n 9 above, 1523

33 Commission Communication on Regional Protection Programmes COM(2005) 388 final. 
have aside from those explicitly required by law? How do they differ from those refugees who never reach European shores?

These individuals are essentially those who find some way to circumvent, either legally or illegally, the EU and the Member State's restrictive control measures designed to deflect asylum seekers. That this is the design of these measures is no secret. Take for example the UK, where a Home Office Asylum Statistical Bulletin of 2006 includes a section entitled 'Key changes to reduce the number of asylum applications'. ${ }^{34}$ A list of measures designed to prevent the arrival of asylum seekers follows, including the introduction of non-suspensive appeals, safe countries, restricted access to socio-economic support for asylum seekers, accelerated procedures and new visa requirements. All these measures, alongside existing restrictive instruments such as carrier sanctions, have facilitated the limitation of regular access to UK asylum procedures.

The recent events concerning the Iraqi interpreters who help the British forces in Iraq being unable to apply for asylum in the UK and being reduced to pleading with the British government to make an exception and allow them to make their claims from Iraq, or the neighbouring countries to which some have fled, illustrates the failure of UK asylum law to protect some of the individuals most at risk of persecution. Instead of being permitted to claim asylum directly, the British government has insisted that asylum claims be lodged from inside the UK, advising the interpreters to consult the Government website for information on how to apply for a visa. ${ }^{35}$ Considering the above discussion on the use of measures such as visa requirements to act as impediments to the making of asylum claims, it is unreasonable and objectionable, though unsurprising, that the British government presents the control measure as a possible solution to limited access to asylum procedures. Without the economic resources or connections to reach the UK, the interpreters have been able to do little more than risk crossing the Iraqi border into a neighbouring country in order to find some level of protection.

The UK is of course not the only European State to have gradually reduced the number of legitimate access routes open to asylum seekers. The situation is worsening with the expansion of the Union, which places pressure on new and accession States to protect the EU's external borders. In Bulgaria for example strict migration control at both the local and the regional level in line with the accession process is believed to have contributed to the large drop in the country's number of asylum applications. ${ }^{36}$ In Slovenia under review in the Constitutional Court is a new pre-procedure which if introduced will require each asylum applicant to make a statement to the police giving the reasons for her application which if found to be unsatisfactory will lead to a denial of access to the asylum procedure. ${ }^{37}$ In 2005 France increased the number of countries subject to visa

${ }^{34}$ T. Heath, R. Jeffries and S. Pearce, Home Office Statistical Bulletin: Asylum Statistics 2005, 22 August 2006, 8.

35 See reports of The Times of Tuesday, $7^{\text {th }}$ August 2007.

This is the UK Government's position at the time of writing.

${ }^{36}$ ECRE Country Report 2005, 16.

37 ibid. 
requirements, a special transit visa for airports and ports was created, and French immigration liaison officers were stationed in various third country airports in order to check the documents of individuals onboard aeroplanes travelling to France after they have been checked by local officials. Belgium and the Czech Republic transposed Directive 2001/51 on carrier obligations. ${ }^{38}$ Under this Directive those bringing individuals without the required travel documents into Member States are responsible for their return and for any cost incurred by hosting them on Member State territory. In the UK, the New Immigration, Asylum and Nationality Act 2006 contains provisions strengthening border controls by requiring the fingerprinting of all visa applicants and electronic checks are required on all people on both entry to and exit from the country. ${ }^{39}$ The Border Guards in Finland have since 2005 had greater powers, which previously only belonged to the police, over non-nationals who they can now detain for a maximum of 48 hours and asylum seekers can be interviewed in order to ascertain their identity, travel route and means of entry. ${ }^{40}$

These Europe-wide restrictive measures have implications for the makeup of the European refugee. Only individuals who can overcome these obstacles in either a legal or an illegal manner have the possibility of accessing Member State asylum procedures. To enter the EU legally the correct travel documents must first be obtained. To enter illegally, a smuggler would need to be paid to facilitate the journey to Europe. The former group would have to be placed sufficiently high in terms of status and resources at their disposal in order to be able to acquire a visa, while the latter group would have to be similarly situated at least in terms of resources to be able to pay a smuggler's fee that can be in the realm of the equivalent of 4000 euros. ${ }^{41}$ As Noll puts it, in the business that is human smuggling, 'protection is a commodity sold to a middle class of protection seekers'. ${ }^{42}$ Resorting to the use of a smuggler also 'presupposes the acceptance of high risks by migrants'. ${ }^{43}$ Hundreds of migrant deaths have occurred in recent decades for example in the part of the Adriatic Sea between Italy and Albania as smugglers frequently overload dangerous vessels. ${ }^{44}$

The result is that those individuals who succeed in reaching European shores and claiming asylum are by no means the most disadvantaged and vulnerable refugees. Neumayer points out, 'Democratic countries restrict the entry, but rarely the exit, of citizens, whereas harsh autocracies often impose limitations on leaving the country. ${ }^{45}$ By imposing strict access conditions, Member States make it

\footnotetext{
${ }^{38}$ Directive 2001/51 EC of 28 June 2001, OJ L 187, 10.7.2001.

$39 \mathrm{n}$ above, $17-18$.

40 ibid 18.

${ }^{41}$ See http://news.bbc.co.uk/2/hi/uk_news/3083735.stm\# where a sum of $\$ 6000$ is cited as the average smuggler's fee. (Last visited 21 November 2007).

42 G. Noll, "From "Protective Passports" to Protected Entry Procedures? The Legacy of Raoul Wallenberg in the Contemporary Asylum Debate', UNHCR Working Paper, No. 99, December 2003, 1. 
increasingly difficult for potential asylum seekers to seek protection through legitimate means, forcing many to resort to the use of smugglers in order to penetrate the borders of European States. Thus to leave one's country of persecution often requires money to bribe security officials and further finances for the legal or illegal journey to Europe. Most European refugees are therefore often among the most powerful, daring, well-resourced and economically mobile of the persecuted.

It is important to take into account these implied characteristics of the European refugee when determining the state of European refugee law. With a clearer picture of European refugee law in the context of Europe's wider migration policy, it ought to be possible to draw some conclusions on the nature of the evolving Common European Asylum Policy (CEAS). If it is true that only asylum seekers fulfilling certain requirements over and above those contained in express refugee law, such as being economically mobile, can access the EU, then the new European refugee is by no means the most vulnerable. The fact that certain migrants are privileged over others means that the CEAS is far from an equitable regime in neither granting sufficient nor equal access to its asylum procedures. Furthermore it may be argued that the system lacks prudence as a refugee regime in dedicating scarce resources to an inefficient and stunted regime which protects the more 'powerful refugee' over the most vulnerable. In its allocation of rights and benefits to a select number of individuals in a manner that has until now paid insufficient regard to those refugees in need of protection, but who lack the capabilities to penetrate the EU's wall of restrictive measures, we are also entitled to question the normative foundation of the CEAS.

\section{THE EU POLICY RESPONSE}

One of the many questions arising from the above characterisation of the new European refugee is whether these results are intended, or an unfortunate, incidental outcome of the way in which EU migration policy interacts with its asylum legislation. It is clear from the documentation that the EU institutions and the Member States are aware of the impact of the new policies at least in so far as they act to reduce access for asylum seekers to the EU. However, the difficult question remains as to whether it is possible to counter adequately such resulting negativities whilst retaining restrictive measures on access in place. What is clear from the recent Green Paper on the future of the CEAS 46 is that the Commission's intention is to remedy the negative effects of the restrictive measures through the introduction of new measures rather than by dismantling some of the deflective aspects of the current system, such as strict visa requirements for refugee-producing countries. Accordingly, the Commission perceives the need for 'further measures' that 'could be taken to ensure that the

${ }^{46}$ Green Paper on the future of Common European Asylum System, Brussels, 6.6.2007 COM(2007) 301 final. 
implementation in practice of measures aimed at combating illegal migration does not affect the access of asylum seekers to protection'. ${ }^{47}$ It is clear that the Commission realises that the removal of the restrictions on access themselves politically will not be an option for Member States and it opts for putting forward proposals to counter their negative effects. In what follows, this paper also addresses the question of what can realistically be achieved in terms of increasing access to EU asylum procedures within the current restrictive framework, rather than futilely demanding the removal of the restrictions.

Conclusion 26 of the June 2003 Thessaloniki European Council had invited the Commission 'to explore all parameters in order to ensure more orderly and managed entry in the EU of persons in need of international protection'. ${ }^{48}$ This was reiterated in 2005 when the European Council underlined the need for a 'balanced, global and coherent approach' to migration ${ }^{49}$ and again in 2006 where the need for 'due access to asylum procedures' 50 was emphasised. In 2003, the Commission responded with a Communication in which it recognised that the evident fall in the number of asylum claims made in the EU did 'not necessarily mean an overall reduction in the numbers of refugees and persons seeking international protection at a global level'. ${ }^{51}$ Further, the Commission noted the 85 per cent of refugees being hosted by countries in regions of origin struggling with limited resources. In fact 6.5 million of the World's 8.7 million refugees are estimated to live in developing countries. ${ }^{52}$ The Commission recognised the need to 'reform the international protection regime to make it more accessible, better managed and first and foremost more equitable'. ${ }^{53}$ Despite the long acknowledged problem of insufficient access to EU asylum procedures, it is clear from the recent Green Paper on the future of the Common European Asylum System that little progress has been made to alleviate the restrictions on access for asylum seekers. ${ }^{54}$ Through consultation the Green Paper is designed to enable the Commission to produce a policy plan in early 2008 outlining the measures to be adopted to construct the CEAS. The Commission highlights the problem of 'mixed flows' where the individuals arriving at Member States' borders include illegal immigrants as well as asylum seekers and perceives the solution as involving the 'guaranteeing and enhancing' of 'access to protection at external borders'. ${ }^{55}$

Following the 2003 Communication recognising the need for fair access to European asylum procedures ${ }^{56}$ the Commission produced a more operational

47 ibid 14.

48 Conclusion 26 of the Thessaloniki European Council of 19/20 June 2003.

${ }^{49}$ Conclusion 8 of the Brussels European Council of 15/16 December 2005.

50 Conclusion 22 of the Brussels European Council of 14/15 December 2006.

51 Commission Communication of June 2003, Towards more accessible, equitable and managed asylum systems, at [7].

52 UNHCR Statistical Yearbook 2005, cited in the Green Paper on the future of Common European Asylum System, Brussels, 6.6.2007 COM(2007) 301 final, 12.

53 See $n 51$ above.

54 See n 46 above.

55 ibid 14.

56 See n 51 above. 
Communication in 2004, in which the findings of two studies are presented. The first looks at the possibility of processing asylum applications outside the EU and the second explores the feasibility of establishing resettlement schemes in Member States or at the EU level. Both these responses are to be welcomed as potential means of allowing greater access to European asylum procedures. The Hague Programme followed in 2004 in which the need for 'a comprehensive approach' to migration was once again reiterated. Such an approach is to involve 'strong and effective coordination between those responsible for migration and asylum policies and those responsible for other policies relevant to these areas'. ${ }^{57}$ Since these statements however it seems that the greatest action has been taken in the sphere of enhancing cooperation with third countries and regions of origin rather than taking direct steps to increase the access opportunities for asylum seekers to the EU.

In recognition of the negative implications of EU migration law and policy on asylum, the European Commission has put forward a number of proposals in order to move towards the goal of a 'comprehensive approach to asylum and migration'.58 Though little acted upon as yet, the need for such an approach has long been acknowledged in the EU. The Tampere European Council of October 1999, and each following, has underlined the importance of an integrated approach to asylum and migration involving cooperation with regions of origin and third countries.

In the Communication on Regional Protection Programmes (RPPs), the Commission acknowledges that the fall in the number of asylum seekers in Europe does not mean a fall in the number of refugees and asylum seekers in the World. ${ }^{59}$ RPPs are a result of the recognition that many of the most vulnerable refugees remain in neighbouring countries in their regions of origin. By financially assisting and otherwise closely cooperating with refugee hosting countries in these regions, the Commission foresees that refugees will be able to gain the protection they need 'as quickly as possible and as closely as possible'. ${ }^{60}$ The aim of RPPs is to increase 'protection capacity' in regions of origin by providing their refugee populations with 'Durable Solutions' perceived preferably as repatriation or local resettlement and failing these, resettlement in a third country. ${ }^{61}$ In its Conclusions of November 2004, the European Council stated that the pilot RPPs to be proposed by the Commission should include a number of important aspects, such as aiding third countries to comply with the Refugee Convention obligations and those of other relevant international instruments, measures to enhance protection capacity, assistance in improving the local infrastructure and migration management. RPPs are to develop in close cooperation with the UNHCR, in line with the Memorandum of Understanding between the Commission and the

57 Conclusion 12, The Hague Programme, Strengthening Freedom, Security and Justice in the European Union, Presidency Conclusions, Brussels 4/5 November 2004.

58 ibid.

${ }^{59}$ See $\mathrm{n} 33$ above, 1.

60 ibid.

61 ibid 2. 
UNHCR of 15 February 2005. ${ }^{62}$ However, there is to be no new financial arrangements for RPPs and funding will come from the AENEAS and TACIS financial frameworks. ${ }^{63}$

It may be that the notion of RPPs has a number of benefits for the selected regions of origin as well as refugees themselves. Some core features of RPPs include ensuring that projects improve the general situation of protection in host countries, establishing effective refugee determination procedures, improving reception conditions, ameliorating the impact of refugees on local populations by disseminating information on the positive impact of refugees, finally and perhaps most important with regard to the cooperation element of RPPs, Member States are to make a resettlement commitment, whereby they undertake to provide protection for a number of affected refugees on their own territories. ${ }^{64}$

The Commission's concept of RPPs has recently been launched in two pilot Programmes, in the Western Newly Independent States and in Tanzania. These regions were selected in coordination with the UNHCR, which initially identified 38 refugee situations which could be considered protracted and therefore warrant Community partnership in resolving problems. In each region at least 25,000 refugees had been living in exile for a period of more than five years. Tanzania, for example, was considered suitable for an RPP on account of its being the host of the largest number of refugees in Africa. ${ }^{65}$ The choice of regions to be assisted also depends on available Community funds and existing relationships of cooperation between the Community and relevant countries as well as an institutional framework in order to form a foundation for the creation of an RPP. ${ }^{66}$

The Western Newly Independent States (Ukraine, Moldova and Belarus), forming a transit region, proved a popular choice for Member States in which to set up an RPP. Rather than refugees making their way through these States to Europe, they would instead be protected there with the aid of the EU. This region was also attractive on account of its pre-exiting ties with the Community, allowing the RPP to take the form of increased cooperation. Interestingly, the Commission Communication on RPPs states that the indicative amount granted by the AENEAS fund is 2 million euros. ${ }^{67}$ This does not appear to be a high enough sum of money for such a large region of origin. The Commission has expressed the concern that it is difficult to see how [an RPP] with the limited funds available under AENEAS would have any lasting impact'.68 To put budgetary matters in perspective, in contrast to the RPPs, the EU has pledged 400 million euros to its Culture 2007 programme in the EU. As a result the Commission sees itself as

\footnotetext{
62 ibid 3.

63 ibid.

64 ibid 4.

65 ibid 7.

60 ibid 5.

${ }^{67}$ In respect of Tanzania, the indicative budget assistance to refugees in sub Saharan Africa for 2005 is $€$ 4 million. A further $€ 5$ million is indicated for actions linked to migration management. See ibid 7 .

68 ibid 6-7.
} 
limited to selecting regions where an infrastructure for cooperation is already in place to be built upon, running smaller scale programmes for smaller regions with the hope of future expansion, and in all cases with Member State resettlement schemes running in conjunction with the RPP. ${ }^{69}$ These projects remain at the early stage of implementation and thus their results are yet to emerge and be evaluated. The question remains whether the potential benefits of RPPs for the affected host countries in regions of origin can in anyway allow them to act as a substitute for increased equitability in access to protection in the EU?

In its 2004 Communication on managed entry of persons in need of international protection ${ }^{70}$ the Commission discussed the possibility of the implementation of an EU wide resettlement scheme, highlighting the advantages of conveying the message that the EU is prepared to take its share of the World's refugees, the possibility of identifying those most and genuinely in need of protection prior to the arrival of individuals in the EU, the reduction of the need for those seeking protection to resort to paying smugglers for a passage into the EU and finally, with the predetermined credibility of the claims of selected individuals there would result an increased acceptance among European citizens of the arrival of refugees in Member States. ${ }^{71}$

Resettlement consists of one of the durable solutions to protracted refugee situations. Resettlement involves the selection and transfer of refugees from a state in which they have sought protection to a third state which has agreed to admit them with permanent residence status'. ${ }^{72}$ Resettlement has proved an attractive proposal to Member States because of its offering the opportunity for selection of refugees and its seeming potential to allow for 'managed and orderly arrival of persons in need of international protection'. ${ }^{73}$ However, it has been demonstrated that resettlement schemes cannot adequately act as a means to curb 'spontaneous arrivals in the EU of persons in need of international protection unless careful attention is paid to selection criteria and numerical targets'. ${ }^{74} \mathrm{~A}$ study on resettlement in the EU conducted by the Migration Policy Institute found that although resettlement may be said to consist of an aspect of the management of refugee protection, there is little evidence to show that it is directly connected to managing the entry of people arriving unsolicited to apply for asylum. Instead it permits the entry of 'more managed arrivals of people in need of international protection in those states with resettlement programmes'. ${ }^{75}$

69 ibid 7.

${ }^{70}$ Commission Communication 'On the Managed Entry in the EU of Persons in Need of International Protection and Enhancement of the Protection Capacity of the Regions of Origin: Improving Access to Durable Solutions' (COM(2004) 410 final, 4 June 2004).

${ }^{71}$ Ibid at [15].

${ }^{72}$ Migration Policy Institute, 'Study on the feasibility of setting up resettlement schemes in EU Member States or at EU level, against the background of the Common European Asylum System and the goal of a Common Asylum Procedure', (2003), 6. Available at http://ec.europa.eu/justice_home/doc_centre /asylum/studies/docs/resettlement-study-full_2003_en.pdf (Last visited 21 November 2007).

73 ibid 7.

74 ibid.

75 ibid 29. 
There are of course a number of problems traditionally associated with resettlement programmes, such as an element of 'cherry-picking' in the selection criteria of refugees to be included in the scheme. The question of the selection criteria for any such EU wide scheme is important with regard to the determination of the characteristics of the European refugee. What will the criteria for selection be? Will there merely be a requirement of vulnerability, or must a selected refugee also possess other traits such as labour skills, education, linguistic, family or other connections with the receiving Member State? Ideally these aspects would only become relevant at the stage of determining the divergent criteria to be applied in respect of an EU wide resettlement, allowing for the initial selection criteria to be predominantly based on need for protection and vulnerability. However, in the event that the resettlement scheme applies solely to those with optimum prospects of integration, it will be unlikely to affect the identity of the European refugee characterised as a narrow and selective one.

The UK operates two resettlement programmes at present, the Mandate Refugee scheme and the Ten or More plan. These schemes however provide a narrow scope of protection, being limited to those who can demonstrate family ties in the UK in the case of the former scheme, while the latter is specifically for individuals, as opposed to families, who can show they require medical attention not provided in their current State. ${ }^{76}$ Interestingly, one of the stated goals of the UK's resettlement programme is to 'remove from those most vulnerable refugees a perceived need to seek the services of a human smuggler if they want to reach the UK'.77 As discussed above, it is however not the most vulnerable refugees who can conceive of paying a smuggler's fare for passage to Europe in order to seek protection. Although the general criteria for selection of refugee participants in its resettlement programmes is generally broad enough to enable the selection of the most vulnerable refugees, there are various Immigration and Nationality Directorate policies that may lead to the practical imposition of further requirements, such as family reunification policies, existing resettlement roots in the form of 'close ties' and existing arrangements to cater for health needs of refugees. ${ }^{78}$

Finally, the Commission has explored the possibility of introducing Protected Entry Procedures (PEPs). These would allow an asylum seeker to approach a Member State outside its territory with her asylum claim and to be granted a residence permit in the case of a positive outcome. These procedures are seen as reducing the need to resort to illegal and dangerous attempts to enter the EU.79 Faced with resistance from Member States to the instigation of PEPs, the Commission decided to abandon the notion as a standard policy and consider it instead as an 'emergency strand' of wider resettlement policy to be implemented

76 ibid 64

77 ibid 63.

78 ibid 65 .

${ }^{79} \mathrm{n} 70$ above, at [35]. 
procedurally at the discretion of each Member State. ${ }^{80}$ Unlike with resettlement schemes where refugee determination takes place in the host country in the region of origin, in the case of protected entry, the determination takes place within the EU following a 'screening process'. ${ }^{81}$

Member States' reluctance to agree to EU wide entrenchment of PEPs is unsurprising. Already believing themselves to be dealing with too many spontaneous arrivals of asylum seekers, the notion of actively protecting the passage of asylum seekers into their States by allowing them to seek asylum outside their territories is clearly objectionable to Member States. Predictably, the perception that some sort of moral responsibility rests with Member States to aid asylum seekers in accessing their territories, particularly in light of the high number of measures restricting movement, is lacking among the majority of States. Noll has sought to determine whether there exists a legal obligation on States to permit entry within the context of Protected Entry Procedures, specifically by questioning whether there is a legal right to an entry visa where an individual is at risk of persecution or other relevant ill treatment. ${ }^{82}$ After exploring international refugee and human rights law, Noll concludes that the obligation, if one can be said to exist, is a 'weak' one. ${ }^{83}$ Importantly however, he makes the point that States are nevertheless required 'to be observant about the aggregate outcome of their migration and asylum policies'. ${ }^{84}$ It is hoped that the result of the trial RPPs will lead to a greater willingness among Member States and the Community Institutions to explore further possibilities of schemes which counter the negative effects of the interaction of their asylum and migration policies through increasing access possibilities for vulnerable asylum seekers.

The UNHCR, in response to the Commission's proposals, has commented that 'While ensuring effective protection and access to durable solutions in regions of origin should reduce pressures for irregular onward movement of persons in need of international protection, this should not preclude access to safety and to an asylum procedure for persons arriving spontaneously. ${ }^{85}$ It is uncertain whether PEPs, RPPs and resettlement schemes could ever be applied in such as way as to fully counter the effects of the EU's restrictive migration measures on genuine asylum seekers. We are yet to see progressive steps being taken to implement these proposals and are far from perceiving their practical results. However, even if they are successfully implemented and more legal routes are created for individuals to seek asylum, the restrictive measures designed to curb illegal immigration and to reduce the overall number of individuals seeking protection in Europe will stay in place. As a result, there will always be those who remain unaided in their attempts

\footnotetext{
80 ibid.

81 ibid

82 G. Noll, 'Seeking Asylum at Embassies: A Right to Entry under International Law?' (2005) IJRL 574.

83 ibid 575.

84 ibid.

${ }^{85}$ UNHCR Observations on the European Commission Communication 'On the Managed Entry in the EU of Persons in Need of International Protection and Enhancement of the Protection Capacity of the Regions of Origin: Improving Access to Durable Solutions' (COM(2004) 410 final, 4 June 2004) 1.
} 
to seek protection and who find themselves hindered by Europe's restrictive migration measures, and these individuals are likely to be amongst the most vulnerable refugees.

These questions are important in order to establish the true nature of the CEAS and the way in which it is managed. The fact is that while States have been concentrating on keeping as many asylum seekers out as possible, the nature of refugee law and the European refugee has been changing as particular migrants are kept out whilst those who have the ability to circumvent Member States' restrictive measures have a means of accessing protection. The EU may think it is clamping down on illegal and legal migration of certain undesirables into the EU, but in reality it is only doing so for the most vulnerable of migrants, whether bona fide refugees or not. This not only disadvantages the most vulnerable but unjustifiably privileges certain others. The project of the construction of a European refugee law has not been presented and accepted on such a premise. Nowhere is such inequity a stated objective of European refugee law. It must be recognised that the restrictive migration policies of the EU make it impossible for it to claim the existence of a principled foundation for the management and application of its asylum legislation, even if the legislation itself can be said to provide a wide scope of protection on paper. Its restrictive migration policy has cost Europe the equity of its asylum law. European refugee law protects a select group of somewhat privileged refugees. Even where a refugee has to sell all her belongings to pay a smuggler to take her to Europe, she is privileged in comparison to the refugee who has nothing to sell.

It is crucial to recognise that while the restrictive measures on access remain in place, protection measures in the regions of origin become extremely important. At present Member States' ambivalence towards these schemes, particularly PEPs, is not a promising sign. With limited budgetary allowances being invested in the establishment of RPPs for example, there is clearly much progress to be made in ensuring that these protection programmes adequately contribute to countering the negative implications the EU's restrictive migration policy has on those seeking to access asylum procedures in Europe. Though such migration management schemes tend to be regarded with a measure of scepticism and mistrust, they potentially present the most pragmatic and immediate solution for a substantial number of the most vulnerable refugees. The efficacy of the schemes depends essentially on how seriously Member States take them. Sufficient resources must be directed at RPPs and resettlement programmes. Protected Entry Procedures, so far scorned by Member States should be perceived as a fair and necessary measure in light of the many restrictive instruments preventing asylum seekers from accessing Europe. 


\section{CONCLUSION}

The face of European refugee law is changing, and with it the character of the European refugee. In many ways, the European refugee is better treated than ever before; guaranteed wider and equitable protection in each Member State. However, in other respects, the category has become exclusionary when seen in the light of wider European migration policy. The inherent mistrust in the credibility of the European asylum seeker has led to the creation of a wall of restrictive policies designed to make the arrival of asylum seekers and illegal immigrants more difficult. However, these restrictions have in turn had the effect of filtering out certain refugees from the category of the European refugee, no doubt a great number of them genuine. Not only must a European refugee fulfil the requirements set out in the Qualifications Directive, but she must also possess certain other, implicit characteristics: financial resources, economic mobility and an element of power. Though a number of the persecuted possess these traits, the most vulnerable do not. Whether or not these effects on the European asylum regime were intended or merely incidental to its construction, this is the impact on the European refugee.

There are positive steps being taken to tend to the limitation of access to Europe's asylum procedures. With the first Regional Protection Programmes awaiting evaluation, there is hope that the effort being made to improve prospects of protection for refugees in regions of origin will gain momentum. More regions may benefit in the future and it is hoped that funding will increase as the benefits of the schemes become visible. In turn, if the foreseen EU-wide resettlement scheme progresses well, in an equitable and earnest manner, and Protected Entry Procedures are taken more seriously by Member States as consisting of fair and necessary measures to ensure that legal access routes into the EU for vulnerable asylum seekers and refugees remain open, the characteristics of the new European refugee may well not be set in stone. 